\title{
A mast fruiting episode of the tropical tree Peltogyne purpurea (Caesalpinaceae) in the Osa Peninsula, Costa Rica
}

\author{
Oscar J. Rocha ${ }^{1,2}$, Braulio Vílchez ${ }^{3}$ \& Ana L. Araya Anchetta ${ }^{1,2}$ \\ 1 Escuela de Biología, Universidad de Costa Rica, Ciudad Universitaria Rodrigo Facio, San Pedro de Montes de Oca, \\ 2060 San José, Costa Rica \\ 2 Department of Biological Sciences, Kent State University, P.O. Box 5190, Kent, Ohio, 44242; orocha@kent.edu; \\ aaraya@kent.edu \\ 3 Departamento de Biología, Instituto Tecnológico de Costa Rica, Cartago, Cartago, Costa Rica; bvilchez@itcr.ac.cr
}

Received 21-VIII-2003. C Corrected 08-IX-2005. Accepted 02-VI-2006.

\begin{abstract}
The existence of mast fruiting has not been well documented in the Neotropics. The occurrence of a mast fruiting episode in the population of the tree Peltogyne purpurea in the Osa Peninsula of Costa Rica is described. In February and March of 2000 most of the trees of this species produced a large fruit crop, compared with 1995-1999, when the number of fruit producing trees was very low or zero and those that did bear fruit, did so at a low intensity. In contrast, the fruit crop of 2000 was massive, all trees examined produced fruits and the intensity of fruiting was maximal. There is not enough information on the event for a hypothesis to be formed because the climatic or biological cues that triggered this sporadic flowering are unknown and there is no meteorological data available for this area. Populations with this mode of reproduction may experience local extinction bacause of logging operations. Rev. Biol. Trop. 54 (4): 1151-1155. Epub 2006 Dec. 15.
\end{abstract}

Key words: fruit production, masting, phenology, supra-annual reproduction, Peltogyne purpurea.

It is known that some trees have mast fruiting years (Janzen 1967, 1971, Ratchke and Lacey 1985, Kelly 1994, Kelly and Sork 2002). This is the synchronous intermittent production of large seed crops in perennial plants (Kelly and Sork 2002). Typically, years with vigorous seed production are interspersed among years in which trees are sterile or nearly so (Bawa and Ng 1990, Kelly and Sork 2002). Evolution of this reproductive pattern may be attributed to the pressure of seed predators (Janzen 1974, Silvertown 1980) or to pollination efficiency (Kelly 1994). The former hypothesis is particularly important in those species that suffer high seed predation, and where the chance of escaping predation are much higher in masting years than in any other year (Janzen 1971, 1974, Silvertown 1980). The latter is important in those species where pollination is limited and masting results in a disproportionate increase in fertilization and seed set (Smith et al. 1990, Kelly 1994).

The existence of mast fruiting has not been well documented in the Neotropics. The phenology of neotropical trees has been studied by several authors (Frankie et al. 1974, Opler et al. 1976, Opler 1980, van Schaik et al. 1993). Newstrom et al. (1994a, b) classified the long-term patterns of flowering of humid lowland tropical plants at La Selva Biological Station in Costa Rica. They found that the most common pattern at La Selva is irregular subannual flowering, followed by regular annual flowering, and that continual and supra-annual patterns are not well represented there. Other studies have shown that flowering and fruiting of some tree species do not follow annual cycles, making it difficult to predict fruiting 
episodes (Ng and Loh 1974, Newstrom et al. 1994a, b).

It is not clear what triggers flowering and seeding in plants showing supra-annual patterns. In the Old World family Dipterocarpaceae, mast fruiting is infrequent, and it is synchronized at intervals of several years, but there is out of phase sporadic fruiting by one or several individuals (Chan 1980, Manokaran and Swaine 1994, Sakai et al. 1999). Mast fruiting in Dipterocarps is assumed to result from a drop of approximately $2{ }^{\circ} \mathrm{C}$ or more in minimum night-time temperature for three or more nights in a row (Ashton et al. 1988). Rain may also be an important factor for timing and spacing for flowering at least in some tropical plants (Tyrrel and Coe 1974, Opler et al. 1976, Monasterio and Sarmiento 1976, Reich and Borchert 1982). However, others have argued that weather alone can not be responsible for masting (Kelly 1994, Kelly and Sork 2002).

Janzen $(1967,1971)$ provides alternative hypotheses for induction of flowering and seeding trees. He proposes that the peak of flowering in dry forest trees is the result of selection for sexual reproduction at the most opportune time of the year, and not the result of "immutable physiological processes which can only occur at that time of the year". He claims that flowering and seeding during the dry season eliminates interference of sexual reproduction with vegetative processes and allows for the maximization of the use of pollinators and dispersal agents (Janzen 1967). He also proposes that the intermittent seed crop may reduce losses of seeds due to predation (predator satiation hypothesis) (Janzen 1971, 1974, Silvertown 1980). However, Reich and Borchert (1982) argue that there is no reason to assume that flowering in the dry forest tree T. chrysantha might have evolved as a consequence to the interaction with biotic factors such as the availability of pollinators as proposed by other authors (Janzen 1967, Frankie et al. 1974, Gentry 1974).

P. purpurea (Pittier) (Caesalpinaceae) is an important timber species in Costa Rica. It is restricted to few forest patches in
Southwestern Costa Rica and Northwestern Panama (Holdridge and Poveda 1975, Jiménez and Poveda 1991). P. purpurea is often a dominant species. In the region of Mogos in the Osa Peninsula of Costa Rica, the importance value index (IVI) of this species is second among all timber trees (Table 1). Because of its economic value, $P$. purpurea is being intensively harvested in the Osa Peninsula of Costa Rica, despite being considered a threatened species (Jiménez 1993). Here, we report the occurrence of a mast fruiting episode in P. purpurea in the Osa Peninsula. In addition, we discuss the implications of this finding for the adequate conservation, utilization, and management of this species.

In 1989, one of us (BV) started a project to evaluate the impact of selective logging on the population dynamics of $P$. purpurea. As part of this study, the phenology of 12 trees in the region of Mogos was monitored for two years, using the methodology proposed by Fournier (1974). Four phenological events were defined: leaf flushing, leaf shedding, flowering, and fruiting (green and mature fruits) with each rated according to an arbitrary scale indicating the intensity of the phenological stage. Sampling size and scoring frequency were conducted as proposed by Fournier (1974) and Fournier and Charpantier (1975).

In 1995 and 1996, only four of the twelve trees flowered. However, in 1995 only one tree produced mature fruits, and the intensity of fruiting was low (only $5 \%$ of the crown exhibited fruits). In 1996, only one tree flowered, but it did not produce fruits. In contrast, in 2000, all trees examined produced fruits (a total of thirteen trees were scored for phenological intensity, but we collected seeds for more than forty trees), and the scores obtained for this phenological event indicated that the entire crown was producing fruits (Table 2). In 2001 and 2002, fruit and seed production were similar to that observed during prior years. These findings indicate that in 2000 the reproduction of $P$. purpurea was well synchronized and the intensity of flowering and fruiting was maximal. 
TABLE 1

Relative dominance, relative abundance, relative frequency and importance values of the five most important timber species in the rain forest of Mogos, Osa Peninsula, Costa Rica

\begin{tabular}{|c|c|c|c|c|}
\hline Species & Family & $\begin{array}{l}\text { Relative * } \\
\text { dominance }\end{array}$ & $\begin{array}{l}\text { Relative * } \\
\text { abundance }\end{array}$ & $\begin{array}{l}\text { Relative * } \\
\text { frequency }\end{array}$ \\
\hline
\end{tabular}

$\begin{array}{llllll}\text { Virola koschnyi } & \text { Myristicaceae } & 4.05 & 2.12 & 8.75 & 14.92 \\ \text { Peltogyne purpurea } & \text { Caesalpinaceae } & 7.77 & 1.36 & 5.75 & 14.88 \\ \text { Copaifera camibar } & \text { Caesalpinaceae } & 4.14 & 1.24 & 4.75 & 10.13 \\ \text { Protium spp. } & \text { Burseraceae } & 0.64 & 1.71 & 7.00 & 9.36 \\ \text { Symphonia globulifera } & \text { Clusiaceae } & 1.17 & 1.42 & 5.50 & 8.09 \\ \text { Couratari guianensis } & \text { Lecythidaceae } & 4.25 & 0.65 & 2.75 & 7.65\end{array}$

* calculated according to Mueller-Dombois and Ellenberg (1974), where

$$
\begin{aligned}
& \text { Relative dominance }=\frac{\text { total basal area of the species x } 100}{\text { total basal area of all species }} \\
& \text { Relative abundance }=\frac{\text { number of individual of the species } \times 100}{\text { total number of individuals }} \\
& \text { Relative frequency }=\frac{\text { frequency of a species x } 100}{\text { sum frequency of all species }}
\end{aligned}
$$

Importance value index $(\mathrm{IVI})=$ relative dominance + relative abundance + relative frequency

\section{TABLE 2}

Fruiting trends of P. purpurea in 1995, 1996 and 2000

$\begin{array}{ccccc}\text { Year } & \begin{array}{c}\text { Number of } \\ \text { Trees }\end{array} & \begin{array}{c}\text { Number of } \\ \text { flowering trees } \\ \text { (score \%) }\end{array} & \begin{array}{c}\text { Number of } \\ \text { fruiting trees } \\ (\text { score \%) }\end{array} & \begin{array}{c}\text { Date of fruit } \\ \text { production }\end{array} \\ 1995 & 12 & 4(35) & 1(5) & \text { Nov-Dec } \\ 1996 & 12 & 4(35) & 0(0) & \\ 2000 & 13 & 13(100) & 13(100) & \text { Feb-March }\end{array}$

Number of trees and scores for the intensity of the phenological event (in parenthesis) are given according to Fournier (1974).

The observation presented here seems to fit within the category of supra-annual fruiting proposed by Newstrom et al. (1994a). The last fruiting event might have occurred between nine and twelve years prior to 2000 . We base this assumption in two observations. First, one of us (BV) initiated a demographic study of P. purpurea in 1990 and found only saplings in the understory (Vilchez-Alvarado1998). Second, the first two authors searched for seedlings every year since that time, and never found a single one until 2000. In contrast, in 2000 , seeds were visible on the forest floor, as never observed in previous years and later it was possible to find hundreds of seedlings per square meter around reproductive trees.

There is not enough information on the event for a hypothesis to be formed because the climatic or biological cues that triggered this sporadic flowering are unknown and there is no meteorological data available for this area. 
This species is selectively logged in Costa Rica. However, logging operations do not take into account major reproductive events as the one described above. Typically, it is assumed that the target species follows an irregular sub-annual or regular annual reproductive pattern. Therefore, it is important to study the impacts of such practices on species that show supra-annual patterns in their reproduction. Depending on the magnitude of the impact, targeted populations showing this mode of reproduction may experience local extinction. However, insufficient data makes it difficult to predict the outcome of these practices.

\section{ACKNOWLEDGMENTS}

The authors thank M.E. Zaldívar, M.V. Gutiérrez, and one anonymous reviewer for advice, comments, and/or criticisms on a previous version of this manuscript; L. Castro, E. Castro and G. Aguilar for field assistance. This work was supported by the International Foundation for Science grant (grant IFS 19432), the International Plant Genetic Resources Institute and the Center for International Forestry Research (grants 96/ 073, 97/052, and 98/049), and a University of Costa Rica grant (VI-111-91-223) to O.J. Rocha.

\section{RESUMEN}

Se describe un episodio de fructificación en masa en una población de Peltogyne purpurea de la Península de Osa, Costa Rica. En febrero y marzo de 2000, la mayor parte de los árboles de esta especie tuvo una gran cosecha de frutos. En los años anteriores, desde 1995, ninguno o muy pocos árboles produjeron frutos y la producción por árbol fue escasa. La cosecha del año 2000 fue masiva y todos los árboles examinados produjeron frutos abundantes. Este patrón reproductivo podría producir extinciones locales si la extracción maderera no lo toma en cuenta.

Palabras clave: producción de frutos, fructificación mastal, fenología, reproducción supra-anual, Peltogyne purpurea.

\section{REFERENCES}

Ashton, P.S., T.J. Givnish \& S. Appanah. 1988. Staggered flowering in the Dipterocarpaceae: New insights into floral induction and the evolution of mast fruiting in the seasonal tropics. Am. Nat. 132: 44-60.

Bawa, K.S. \& F.S.P. Ng. 1990. Phenology-commentary, p. 17-20. In K.S. Bawa \& M. Hadley (eds.). Reproductive ecology of tropical forest plants. Parthenon, Paris, France.

Chan, H.T. 1980. Reproductive biology of some malaysian dipterocarps. II. Fruitng and seedling studies. Malay. For. 43: 438-451.

Fournier, L.A. 1974. Un método cuantitativo para la medición de características fenológicas de árboles. Turrialba 24: 422-423.

Fournier, L.A. \& C. Charpantier. 1975. El tamaño de la muestra y la frecuencia de las observaciones en el estudio de características fenológicas de los árboles tropicales. Turrialba 25: 45-48.

Frankie, G.W., H.G. Baker \& P.A. Opler. 1974. Comparative phenological studies of trees in tropical wet and dry forests in the lowlands of Costa Rica. J. Ecol. 62: 881-919.

Gentry, A.H. 1974. Flowering phenology and diversity in tropical Bignoniaceae. Biotropica 6: 64-68.

Holdridge, L.R. \& L.J. Poveda. 1975. Árboles de Costa Rica. Vol. 1. Palmas, otras monocotiledóneas y árboles con hojas compuestas o lobuladas. Centro Científico Tropical, San José, Costa Rica. 546 p.

Janzen, D.H. 1967. Synchrony of sexual reproduction of trees within the dry season in Central America. Evolution 21: 620-637.

Janzen, D.H. 1971. Seed predation by animals. Ann. Rev. Ecol. Syst. 2: 465-492.

Janzen, D.H. 1974. Tropical black water rivers, animals and mast fruiting by Dipterocarpaceae. Biotropica 4: 69-103.

Jiménez, Q. 1993. Árboles maderables en peligro de extinción en Costa Rica. INCAFO, San José, Costa Rica. 121 p.

Jiménez, Q. \& L.J. Poveda. 1991. Árboles maderables nativos de Costa Rica. Museo Nacional de Costa Rica, San José, Costa Rica. 32 p.

Kelly, D. 1994. The evolutionary ecology of mast seeding. Trends Ecol. Evol. 9: 465-470. 
Kelly, D. \& V.L. Sork. 2002. Mast seeding in perennial plants: why, how, where? Ann. Rev. Ecol Syst. 33: 427-447.

Manokaran, N. \& M.D. Swaine. 1994. Population dynamics of trees in dipterocarp forests of peninsular Malaysia. Malaysian Forests Records 40. Forest Research Institute Malaysia, Kuala Lumpur, Malaysia. 173 p.

Monasterio, M. \& M. Sarmiento. 1976. Phenological strategies of plant species in the tropical savanna and the semi-deciduous forest of the Venezuelan Llanos. J. Biogeogr. 3: 325-355.

Newstrom, L.E., G.W. Frankie \& H.G. Baker. 1994a. A new classification for plant phenology based on flowering patterns in lowland tropical rain forest at La Selva, Costa Rica. Biotropica 26: 141-159.

Newstrom, L.E., G.W. Frankie, H.G. Baker \& R.K. Colwell. 1994b. Diversity of long-term flowering patterns, p. 142-160. In L.A. McDade , K.S. Bawa, H.A. Hespenheide \& G.S. Hartshron (eds.). La Selva: ecology and natural history of a neotropical rain forest. Chicago, Chicago, USA.

Ng, F.S.P. \& H.S. Loh. 1974. Flowering-to fruiting periods of Malaysian trees. Malayan Forester 37: 127-132.

Opler, P.A. 1980. Comparative phenological studies of treelet and shrub species in tropical wet and dry forests in the lowlands of Costa Rica. J. Ecol. 68: 167-188.

Opler, P.A., G.W. Frankie \& H.G. Baker. 1976. Rainfall as a factor in the release, timing, and synchronization of anthesis by tropical trees and shrubs. J. Biogeogr. 3: $231-236$

Rathcke, B. \& E.P. Lacey. 1985. Phenological patterns of terrestrial plants. Ann. Rev. Ecol. Syst. 16: 179-214.

Reich, P.B. \& R. Borchert. 1982. Phenology and ecophysiology of the tropical tree, Tabebuia neochrysantha (Bignoniaceae). Ecology 63: 294-299.

Sakai, S., K. Momose, T. Yumoto, T. Nagamitsu, H. Nagamasu, A.A. Hamid \& T. Nakashizuka. 1999. Plant reproductive phenology over four years including an episode of general flowering in a lowland Dipterocarp forest, Sarawak, Malaysia. Am. J. Bot. 80: $1414-1436$

Silvertown, J.W. 1980. The evolutionary ecology of mast seeding in trees. Biol. J. Linnean Soc. 14: 235-250.

Smith, C.C., J.L. Hamrick \& C.L. Kramer. 1990. The advantage of mast years for wind-pollination. Am. Nat. 136: 154-166.

Tyrrel, J.G. \& M.J. Coe. 1974. The rainfall regime of Tsavo National Park, Kenya and its potential phenological significance. J. Biogeography 1: 187-192.

Van Schaik, C.P., J.W. Terborgh \& S.J. Wright. 1993. The phenology of tropical forests: adaptive and consequences for primary consumers. Ann. Rev. Ecol. Syst. 24: $353-377$.

Vilchez-Alvarado, B. 1998. Estudio de una población de Peltogyne purpurea (Pittier) en un bosque intervenido de la Península de Osa, Costa Rica, América Central. Tesis de MSc., Universidad de Costa Rica, San José, Costa Rica. 74 p. 
